\title{
Effects of nitrogen fertilizer applications on the early senescence and grain filling characteristics of Tartary buckwheat
}

\author{
Yu Zhang ${ }^{\dagger}$, Peiyun $\mathrm{He}^{\dagger}$, Shihong Li, Yan Chen, Xinhui Wu, Kaifeng Huang*, Xiaoyan Huang* \\ Research Center of Buckwheat Industry Technology, School of Life Science, Guizhou Normal University, \\ Guiyang 550001 China \\ *Corresponding authors, e-mail: hkf1979@163.com, huangxy666@126.com \\ $\uparrow$ These authors contributed equally to this work.
}

Received $20 \mathrm{Feb} 2021$

Accepted 25 May 2021

\begin{abstract}
This study used four different nitrogen fertilizer applications to determine their effects on early senescence and grain filling of the Tartary buckwheat "cv Jinqiao 2". Changes in grain filling dynamics, starch synthesis enzyme activity, photosynthetic characteristics, antioxidant enzyme activity, malondialdehyde content, agronomic traits, and yield formation were assessed. The shape parameters ( $N$ values) were all lower than 1 for the four applications. Initial growth power $\left(R_{0}\right)$ and maximum grain filling rate $(\mathrm{Gmax})$ were the highest for the middle nitrogen fertilizer application (MN) treatment. The middle filling stage had the largest contribution rate to grain weight, followed by the later filling stage; and the smallest contribution was noted in the early filling stage. The activity of starch synthase initially increased but eventually decreased with the growth period. In addition, the activity of starch synthase was strong under MN and high nitrogen fertilizer application (HN) treatment. Under MN, the net photosynthetic rate, stomatal conductivity, and transpiration rate of JQ2 leaves were high, and the superoxide dismutase, peroxidase, and catalase activities were strong. Moreover, malondialdehyde content was the lowest. The grain number per plant, grain weight per plant, 1000-grain weight, and yield were higher in MN than in the other three treatments. In summary, the suitable nitrogen fertilizer treatment (MN) can enhance the photosynthetic efficiency, promote Tartary buckwheat grain filling, delay premature senescence, and increase the grain weight and final yield.
\end{abstract}

KEYWORDS: Tartary buckwheat, nitrogen fertilizer application, grain filling, early senescence, grain weight and yield

\section{INTRODUCTION}

Buckwheat belongs to the genus Fagopyrum Mill and is an annual herbaceous plant. Fagopyrum species can be classified into two types, namely, common buckwheat (F. esculentum) and Tartary buckwheat (F. tataricum) [1]. This plant is rich in flavones, Dchiral inositol, and other substances [2]. Tartary buckwheat is a food crop with great health value and anti-tumor properties, and it can lower blood pressure as well as blood sugar and lipids [3]. However, its yield is rather low at approximately 1500 to $2400 \mathrm{~kg} / \mathrm{ha}$ [4]. Therefore, achieving the high and stable yield of Tartary buckwheat is of great importance to promote the buckwheat industry.

Grain filling is the last stage of crop yield formation, and it directly affects the degree of grain filling and the final yield $[5,6]$. During this period, crops begin senescence, a programmed death process necessary for crop growth and development, when the function of plant tissues and organs gradually declines until death [7]. The change in leaf color from green to yellow to shedding indicates senescence, and the change in chlorophyll content is a common index used to study the early senescence of leaves [8]. Early senescence is one of the most important factors that limits high crop yield. Premature leaf senescence is related to the metabolism of reactive oxygen species (ROS) [9]. ROS can cause oxidative damage to antioxidant enzyme protein and change the secondary structure of catalase (CAT) enzyme protein, its spatial conformation, and the CAT auxiliary Fe(III) microenvironment [10]. The activity of antioxidant enzyme is positively correlated with the ability of crops to scavenge harmful substances [11]. Early senescence reduces wheat grain thickness leading to yield reduction [12]. Thomas and Smart found that prolonging the life span of functional leaves for 1 day during the mature period of normal rice growth can theoretically 
increase the yield by approximately $2 \%$ and also improve the crop's quality [13]. Therefore, methods that delay the premature senescence of crops have become the key focus of research to solve the urgent problem of high-yield cultivation.

Nitrogen is one of the three nutrients needed for plant growth, and it is closely related to plant senescence and grain yield [14]. Increasing the amount of nitrogen application and delaying the time of the application of nitrogen fertilizer could delay early senescence and improve grain yield $[15,16]$. However, the relationship between nitrogen fertilizer application and buckwheat grain filling characteristics and senescence has been poorly studied. In the current study, the effects of different nitrogen fertilizer applications on early senescence and grain filling characteristics of Tartary buckwheat "cv Jinqiao 2" (JQ2) were investigated. The results would provide a theoretical basis for high-yield Tartary buckwheat cultivation.

\section{MATERIALS AND METHODS}

\section{Plant material and growth}

Tartary buckwheat "cv Jinqiao 2" (JQ2) was provided by the Buckwheat Industry Technical Research Center of Guizhou Normal University, China. The experiment was conducted on March 9, 2019 and March 5, 2020 in the cement pools at the Huangnitang's Cultivation Experiment Station of the Key Laboratory for Cultivation Physiology and Application of Buckwheat of Guizhou, China (Bijie City, Guizhou Province, $922 \mathrm{~m}, 27^{\circ} 05^{\prime} \mathrm{N}$, and $\left.105^{\circ} 71^{\prime} \mathrm{E}\right)$. The soil used comprised yellow loam with $36.52 \mathrm{~g} / \mathrm{kg}$ organic matter, $48.25 \mathrm{~g} / \mathrm{kg}$ available nitrogen, $312.50 \mathrm{mg} / \mathrm{kg}$ available phosphorus, and $132.39 \mathrm{mg} / \mathrm{kg}$ available potassium. Soil $\mathrm{pH}$ was 5.77. Tartary buckwheat was cultivated in cement pools with an area of $2 \mathrm{~m} \times 10 \mathrm{~m} \times 0.3 \mathrm{~m}$ for each test plot, and four nitrogen fertilizer application treatments were prepared. Different nitrogen fertilizers (urea) applied at $0,45,135$, and $225 \mathrm{~kg} / \mathrm{ha}$ were labeled as $\mathrm{ON}$ (CK), LN, MN, and $\mathrm{HN}$, respectively. The optimal application rates of phosphorus (calcium superphosphate) and potassium (potassium chloride) fertilizers were 70 and $5.0 \mathrm{~kg} / \mathrm{ha}$, respectively [4]. Three kinds of fertilizers were thoroughly mixed and used as the base fertilizer. No fertilizer was applied throughout the growth period. The spacing for each row spanned $33 \mathrm{~cm}$, the seeding amount was $52.5 \mathrm{~g} / \mathrm{plot}$, and approximately 900 to 1000 reserved plants were available for each plot (thinning out or supplementing seedlings at seedling stage was applied to maintain planting density). The seeds were harvested ( $70 \%$ of seeds turn brownish yellow) on June 28, 2019 and June 22, 2020. All treatments were done in triplicate. The monthly average temperatures from March to June in 2019 and 2020 were $18.4^{\circ} \mathrm{C}$ and $17.1^{\circ} \mathrm{C}$, and the monthly average sunshine hours were $113.0 \mathrm{~h}$ and $112.5 \mathrm{~h}$, respectively. During the grain filling period, artificial irrigation was carried out according to the principle of "Extreme drought and thoroughly irrigated". All the other periods, watering depended on natural precipitation.

\section{Sample preparation}

At the beginning of the flowering stage, 1000 to 1500 flowers bloomed on the same day and on the same part of the studied JQ2 were marked in each pool. After 1 week, the marked flowers were sampled every 7 days after flowering until maturation. After shelling, half of the individual sampled grains from every period were frozen in liquid nitrogen for $1 \mathrm{~min}$ and then stored at $-80^{\circ} \mathrm{C}$ for starch synthase enzymatic measurement. The other half were dried at $60^{\circ} \mathrm{C}$ to a constant weight and kept for grain filling characteristics analyses.

A week after anthesis, 20 JQ2 plants with similar growth characteristics were carefully harvested every 7 days, and the oxidase activity and malondialdehyde contents were determined.

\section{Determination of grain filling simulation}

Dried grains were weighed to calculate the average dry weight of 100 grains. In accordance with the studies of Liang et al [17] and Wang et al [18], Richards' equation was used to describe the grainfilling process:

$$
W=A /\left(1+B \mathrm{e}^{-K t}\right)^{1 / N},
$$

where $W$ is the grain weight of Tartary buckwheat during grain filling, $A$ is the final grain weight at harvest, $B$ is the initial value of parameter, $K$ is the constant growth rate, $N$ is the shape parameter, $t$ is the time after flowering, and $R^{2}$ is the compatibility;

$$
R=(K / N)\left(1-(W / A)^{N}\right), \quad R_{0}=K / N,
$$

$R$ is the relative growth rate, and $R_{0}$ is the initial growth power.

$$
\begin{aligned}
T_{\max . G} & =(\ln B-\ln N) / K \\
G_{\max } & =(K W / N)\left(1-(W / A)^{N}\right) \\
G_{\text {mean }} & =A K /(2(N+2)) \\
D & =2(N+2) / K
\end{aligned}
$$


$T_{\max . G}$ is the time with maximum grain-filling rate, $G_{\max }$ is the maximum grain-filling rate, $G_{\text {mean }}$ is the mean grain-filling rate, and $D$ is the active growth duration of grain filling.

\section{Determination of divided grain-filling stage}

Referring to Yang et al [19], the contribution rates of the grain-filling period includes the early (prophase) of filling stage (RGC1), the middle of filling stage (RGC2), and the late (anaphase) of filling stage (RGC3) for grain weight, and they were calculated as follows.

$$
\begin{aligned}
& \mathrm{RGC} 1=W 1 / A \times 100 \% \\
& \mathrm{RGC} 2=(W 2-W 1) / A \times 100 \% \\
& \mathrm{RGC} 3=(W 3-W 2) / A \times 100 \%
\end{aligned}
$$

\section{Starch synthase activity}

With respect to Yang et al [20], the activities of adenosine diphosphate glucose pyrophosphate (AGPase), soluble starch polymerase (SSS) were determined, and the activity of starch branch enzyme (SBE) was determined by referring to Nakamura et al [21].

\section{Determination of photosynthetic characteristics}

LI-COR-6400 portable photosynthetic meter (Li-Cor 6400 portable photosynthesis measurement system, Li-Cor, Lincoln, NE, USA) was used to determine the net photosynthetic rate, stomatal conductivity, and transpiration rate of the JQ2 leaf samples (sections 3 to 4, from top to bottom). Measurements were obtained between 10:00 AM to 11:00 AM, and 10 leaves were measured for each treatment.

\section{Determination of antioxidant enzyme activity and MDA content}

In accordance with the research of Zhang [22], the SOD activity was determined by NBT method. POD and CAT activities were measured by ultraviolet spectrophotometer, and MDA content was determined via thiobarbituric acid method.

\section{Determination of agronomic characters and yield}

The agronomic characters and yield of the JQ2 samples, including plant height, number of main stem branches, number of main stem nodes, number of grains per plant, grain weight per plant, 1000-grain weight, and yield, were determined in accordance with the methods of Zhang and Lin [23].
Table 1 The 100-grain weight of JQ2 (g/100 grains DW).

\begin{tabular}{lccccc}
\hline Treatment & $7 \mathrm{~d}$ & $14 \mathrm{~d}$ & $21 \mathrm{~d}$ & $28 \mathrm{~d}$ & $35 \mathrm{~d}$ \\
\hline ON & $0.689^{\mathrm{b}}$ & $1.398^{\mathrm{bc}}$ & $1.680^{\mathrm{b}}$ & $1.908^{\mathrm{b}}$ & $2.369^{\mathrm{a}}$ \\
$\mathrm{LN}$ & $0.639^{\mathrm{c}}$ & $1.278^{\mathrm{c}}$ & $1.699^{\mathrm{b}}$ & $1.903^{\mathrm{b}}$ & $2.442^{\mathrm{a}}$ \\
$\mathrm{MN}$ & $0.804^{\mathrm{a}}$ & $1.733^{\mathrm{a}}$ & $2.059^{\mathrm{a}}$ & $2.138^{\mathrm{a}}$ & $2.291^{\mathrm{ab}}$ \\
$\mathrm{HN}$ & $0.673^{\mathrm{b}}$ & $1.406^{\mathrm{b}}$ & $1.799^{\mathrm{b}}$ & $2.001^{\mathrm{b}}$ & $2.207^{\mathrm{b}}$ \\
\hline
\end{tabular}

\section{Statistical analysis}

Data collected were statistically analyzed by SPSS single-factor ANOVA, and treatment means were compared using least significant difference at 0.05 probability level. There was no significant difference between years. Therefore, the 2019 data were presented in this study, and the data of 2020 were deposited as supplementary data.

\section{RESULTS}

\section{Simulation of grain-filling process}

Differences in 100-grain dry weight were observed among the four different nitrogen fertilizer applications (Table 1). The 100-grain dry weight of MN treatment was the highest. The dry weight of 100 grains of JQ2 increased continuously with the number of days after anthesis.

The determination coefficient $R^{2}$ of each curve equation ranged from 0.986 to 0.998 , indicating that the grouting process of JQ2 fits well with Richards' equation (Table 2). The $N$ value of each nitrogen fertilizer treatment was less than 1 , and the MN treatment's was the smallest. The highest initial growth power $\left(R_{0}\right)$ and the maximum grain filling rate $\left(G_{\max }\right)$ were found with the MN treatment, whereas the time to reach the maximum grain filling rate $\left(T_{\max . G}\right)$ and active filling growth period (approximately $90 \%$ of total growth completed) $(D)$ of the MN treatment was the lowest compared with the other nitrogen fertilizer treatments. The ratio of the growth of maximum grain filling rate to the final value of grain $(I)$ had no significant difference among different nitrogen fertilizer treatments.

\section{Divided grain-filling stage}

The shortest number of days to reach the early filling stage was observed in the HN treatment, and the longest found in the $0 \mathrm{~N}$ treatment. The smallest and the largest average filling rates were found in the MN and HN treatments, respectively (Table 3). The contribution rates of $\mathrm{ON}$ and $\mathrm{LN}$ treatments to grain weight in early filling stage were significantly higher than those of the MN and HN treatments. The number of days to reach the middle and the late 
Table 2 Parameters of the Richards' equation for evaluating the grain-filling process of JQ2.

\begin{tabular}{|c|c|c|c|c|c|c|c|c|c|c|c|}
\hline Treatment & $A$ & B & $K$ & $N$ & $R^{2}$ & $R_{0}$ & $\begin{array}{l}T_{\max . G} \\
\text { (d) }\end{array}$ & $\begin{array}{c}G_{\max } / \\
(100 \mathrm{~g} / \mathrm{d})\end{array}$ & $\begin{array}{l}W_{\max . G} \\
(\mathrm{~g})\end{array}$ & $\begin{array}{c}I \\
(\%)\end{array}$ & $\begin{array}{l}D \\
\text { (d) }\end{array}$ \\
\hline $\mathrm{ON}$ & 2.693 & 0.010 & 0.0724 & 0.0046 & 0.986 & 15.739 & 10.726 & 0.072 & 0.9930 & 36.872 & 55.376 \\
\hline LN & 2.990 & 0.013 & 0.0651 & 0.0058 & 0.989 & 11.224 & 12.398 & 0.071 & 1.1031 & 36.894 & 61.622 \\
\hline MN & 2.239 & 0.007 & 0.1888 & 0.0018 & 0.998 & 104.889 & 7.193 & 0.155 & 0.8244 & 36.821 & 21.206 \\
\hline $\mathrm{HN}$ & 2.243 & 0.010 & 0.1242 & 0.0036 & 0.998 & 34.500 & 8.226 & 0.102 & 0.8266 & 36.854 & 32.264 \\
\hline
\end{tabular}

Table 3 The divided grain-filling stage of JQ2.

\begin{tabular}{|c|c|c|c|c|c|c|c|c|c|c|c|c|}
\hline \multirow{2}{*}{ Treatment } & \multirow{2}{*}{$\mathrm{t}_{1} / \mathrm{d}$} & \multirow{2}{*}{$\mathrm{t}_{2} / \mathrm{d}$} & \multirow{2}{*}{$\mathrm{t}_{3} / \mathrm{d}$} & \multicolumn{3}{|c|}{ Early filling stage } & \multicolumn{3}{|c|}{ Middle filling stage } & \multicolumn{3}{|c|}{ Late filling stage } \\
\hline & & & & $\begin{array}{l}\text { Dur. } \\
\text { (d) }\end{array}$ & $\begin{array}{c}\text { Rate } \\
(100 \mathrm{~g} / \mathrm{d})\end{array}$ & $\begin{array}{l}\text { Cont. } \\
(\%)\end{array}$ & $\begin{array}{l}\text { Dur. } \\
\text { (d) }\end{array}$ & $\begin{array}{c}\text { Rate } \\
(100 \mathrm{~g} / \mathrm{d})\end{array}$ & $\begin{array}{l}\text { Cont. } \\
(\%)\end{array}$ & $\begin{array}{l}\text { Dur. } \\
\text { (d) }\end{array}$ & $\begin{array}{c}\text { Rate } \\
(100 \mathrm{~g} / \mathrm{d})\end{array}$ & $\begin{array}{l}\text { Cont. } \\
\text { (\%) }\end{array}$ \\
\hline & 2.597 & & & 2.597 & & & 17 & & & 50.199 & & \\
\hline LN & 2.412 & 27.21 & 83.074 & 2.412 & & 14.8 & & & & 855 & & 20.340 \\
\hline MN & 2.092 & 12.304 & & 2.092 & & & & & & 19.264 & & 30.683 \\
\hline HN & 0.467 & 16.006 & 45.258 & 0.467 & 0.3532 & 7.354 & 15.539 & 0.088 & 61.012 & 29.252 & 0.0235 & 30.633 \\
\hline
\end{tabular}

Dur., duration; Rate, average rate; Cont., contribution.

Table 4 The starch synthase activity of JQ2.

\begin{tabular}{lcccccc}
\hline Enzyme & Treatment & $7 \mathrm{~d}$ & $14 \mathrm{~d}$ & $21 \mathrm{~d}$ & $28 \mathrm{~d}$ & $35 \mathrm{~d}$ \\
\hline AGPase & ON & $0.419^{\mathrm{b}}$ & $0.486^{\mathrm{b}}$ & $0.613^{\mathrm{a}}$ & $0.503^{\mathrm{d}}$ & $0.281^{\mathrm{c}}$ \\
(U/g) & LN & $0.403^{\mathrm{b}}$ & $0.436^{\mathrm{d}}$ & $0.486^{\mathrm{d}}$ & $0.585^{\mathrm{a}}$ & $0.312^{\mathrm{b}}$ \\
& MN & $0.366^{\mathrm{c}}$ & $0.462^{\mathrm{c}}$ & $0.513^{\mathrm{c}}$ & $0.533^{\mathrm{b}}$ & $0.375^{\mathrm{a}}$ \\
& $\mathrm{HN}$ & $0.457^{\mathrm{a}}$ & $0.492^{\mathrm{a}}$ & $0.548^{\mathrm{b}}$ & $0.513^{\mathrm{c}}$ & $0.284^{\mathrm{c}}$ \\
\hline SSS & ON & $1.672^{\mathrm{b}}$ & $7.856^{\mathrm{a}}$ & $2.578^{\mathrm{c}}$ & $1.827^{\mathrm{c}}$ & $0.822^{\mathrm{b}}$ \\
(U/g) & LN & $4.131^{\mathrm{a}}$ & $7.873^{\mathrm{a}}$ & $7.181^{\mathrm{a}}$ & $4.537^{\mathrm{a}}$ & $0.847^{\mathrm{b}}$ \\
& MN & $4.140^{\mathrm{a}}$ & $7.567^{\mathrm{a}}$ & $6.237^{\mathrm{ab}}$ & $4.502^{\mathrm{a}}$ & $1.453^{\mathrm{a}}$ \\
& HN & $2.721^{\mathrm{ab}}$ & $6.329^{\mathrm{b}}$ & $4.183^{\mathrm{b}}$ & $2.874^{\mathrm{b}}$ & $1.863^{\mathrm{a}}$ \\
\hline SBE & ON & $3.831^{\mathrm{a}}$ & $3.959^{\mathrm{a}}$ & $3.421^{\mathrm{b}}$ & $3.059^{\mathrm{a}}$ & $2.957^{\mathrm{a}}$ \\
(U/g) & LN & $3.438^{\mathrm{b}}$ & $4.047^{\mathrm{a}}$ & $3.235^{\mathrm{c}}$ & $3.272^{\mathrm{a}}$ & $2.600^{\mathrm{b}}$ \\
& MN & $3.310^{\mathrm{c}}$ & $4.048^{\mathrm{a}}$ & $2.951^{\mathrm{d}}$ & $2.229^{\mathrm{b}}$ & $2.175^{\mathrm{c}}$ \\
& HN & $3.994^{\mathrm{a}}$ & $4.012^{\mathrm{a}}$ & $3.883^{\mathrm{a}}$ & $3.273^{\mathrm{a}}$ & $3.181^{\mathrm{a}}$ \\
\hline
\end{tabular}

filling stages was short in MN treatment, while the average filling rate was higher. LN treatment had the longest time to reach the middle filling stage and the lowest filling rate. The number of days to reach the late filling stage was the longest in LN treatment and the smallest in $0 \mathrm{~N}$ treatment. The contribution rates of $\mathrm{ON}$ and $\mathrm{LN}$ treatments to grain weight in middle filling stage were significantly higher than those of the MN and $\mathrm{HN}$ treatments. The contribution rates of MN and $\mathrm{HN}$ treatments to grain weight at late filling stage were significantly higher than those of LN and $\mathrm{ON}$ treatments.

\section{Starch synthase activity}

The AGPase activity in grains of JQ2 initially increased and subsequently decreased with the advancement of growth period; in addition, the $0 \mathrm{~N}$ and $\mathrm{HN}$ treatments reached the maximum at 21 days after anthesis, while the LN and MN treatments were at 28 days (Table 4). The AGPase activity in early filling stage (i.e., $7 \mathrm{~d}$ to $14 \mathrm{~d}$ after anthesis) was the highest in $\mathrm{HN}$ treatment, and the MN treatment was the highest in late filling stage (35 days after anthesis).The JQ2 grain SSS activity reached the highest at the 14th day after anthesis, and then decreased rapidly. Moreover, the MN treatment was the highest among different nitrogen fertilizer treatments. The JQ2 grain SBE activity initially increased, then subsequently decreased with the advancement of growth period, and reached the maximum at 14 days after anthesis. In addition, HN treatment had the highest activity among different nitrogen fertilizer treatments.

\section{Photosynthetic characteristics}

Net photosynthetic rate of leaves increased initially and subsequently decreased with growth period, and the maximum rate was reached at 14 days after anthesis (Table 5). The net photosynthetic rate showed no significant difference among the nitrogen fertilizer treatments at 7 days after flower appearance. Moreover, the net photosynthetic rate of $\mathrm{MN}$ treatment reached the maximum in other periods. The stomatal conductivity of leaves initially decreased, subsequently increased, and then decreased with the advancement of growth period. Stomatal conductivity also reached the maximum at 7 days after anthesis. No significant difference among the treatments of nitrogen fertilizer was noted at 14 and 35 days after anthesis, and reached the maximum with MN treatment. The transpiration rate of leaves initially decreased, subsequently increased, and then decreased with the advancement of growth period, and reached the maximum at 7 days after anthesis. The transpiration rate at 
Table 5 Photosynthetic characteristics of JQ2.

\begin{tabular}{|c|c|c|c|c|c|c|}
\hline Parameter & Treatment & $7 d$ & $14 \mathrm{~d}$ & $21 \mathrm{~d}$ & $28 \mathrm{~d}$ & $35 \mathrm{~d}$ \\
\hline \multirow{4}{*}{$\begin{array}{l}\text { Net photosynthetic rate } \\
\left(\mu \mathrm{mol} \mathrm{CO}{ }_{2} / \mathrm{m}^{2} / \mathrm{s}\right)\end{array}$} & $0 \mathrm{~N}$ & $10.904^{\mathrm{a}}$ & $13.938^{b}$ & $11.210^{\mathrm{b}}$ & $10.339^{b}$ & $7.619^{\mathrm{b}}$ \\
\hline & $\mathrm{LN}$ & $11.196^{\mathrm{a}}$ & $13.368^{b}$ & $11.299^{\mathrm{b}}$ & $10.474^{b}$ & $7.374^{b}$ \\
\hline & $\mathrm{MN}$ & $11.752^{\mathrm{a}}$ & $15.341^{\mathrm{a}}$ & $12.709^{\mathrm{a}}$ & $11.145^{\mathrm{a}}$ & $9.225^{\mathrm{a}}$ \\
\hline & $\mathrm{HN}$ & $10.939^{\mathrm{a}}$ & $13.569^{b}$ & $12.383^{\mathrm{a}}$ & $10.516^{b}$ & $8.363^{\mathrm{a}}$ \\
\hline \multirow{4}{*}{$\begin{array}{l}\text { Stomatal conductivity } \\
\left(\mathrm{mmol} \mathrm{H}_{2} \mathrm{O} / \mathrm{m}^{2} / \mathrm{s}\right)\end{array}$} & ON & $0.072^{\mathrm{ab}}$ & $0.051^{\mathrm{a}}$ & $0.045^{b}$ & $0.059^{\mathrm{ab}}$ & $0.026^{a}$ \\
\hline & $\mathrm{LN}$ & $0.066^{b}$ & $0.054^{\mathrm{a}}$ & $0.048^{b}$ & $0.062^{\mathrm{a}}$ & $0.028^{\mathrm{a}}$ \\
\hline & $\mathrm{MN}$ & $0.084^{\mathrm{a}}$ & $0.060^{\mathrm{a}}$ & $0.055^{\mathrm{a}}$ & $0.068^{\mathrm{a}}$ & $0.029^{\mathrm{a}}$ \\
\hline & $\mathrm{HN}$ & $0.076^{\mathrm{ab}}$ & $0.058^{\mathrm{a}}$ & $0.055^{\mathrm{a}}$ & $0.052^{\mathrm{b}}$ & $0.027^{a}$ \\
\hline \multirow{4}{*}{$\begin{array}{l}\text { Transpiration rate } \\
\left(\mathrm{mmol} \mathrm{H}_{2} \mathrm{O} / \mathrm{m}^{2} / \mathrm{s}\right)\end{array}$} & ON & $3.672^{\mathrm{ab}}$ & $2.183^{\mathrm{a}}$ & $2.295^{\mathrm{a}}$ & $3.302^{\mathrm{ab}}$ & $\overline{1.118^{\mathrm{a}}}$ \\
\hline & $\mathrm{LN}$ & $3.446^{b}$ & $2.605^{\mathrm{a}}$ & $3.059^{\mathrm{a}}$ & $2.824^{\mathrm{b}}$ & $1.268^{\mathrm{a}}$ \\
\hline & $\mathrm{MN}$ & $4.136^{\mathrm{a}}$ & $2.199^{\mathrm{a}}$ & $2.814^{\mathrm{a}}$ & $3.853^{\mathrm{a}}$ & $1.130^{\mathrm{a}}$ \\
\hline & $\mathrm{HN}$ & $3.907^{\mathrm{ab}}$ & $2.392^{\mathrm{a}}$ & $2.738^{\mathrm{a}}$ & $2.861^{\mathrm{b}}$ & $1.257^{\mathrm{a}}$ \\
\hline
\end{tabular}

7 and 28 days after the flower appeared was the largest with $\mathrm{MN}$ treatment. At 7 days after flower, the transpiration rate in $0 \mathrm{~N}, \mathrm{MN}$ and $\mathrm{HN}$ treatment was significantly higher than that in $\mathrm{LN}$ treatment. At 28 after flower, the transpiration rate in $0 \mathrm{~N}$ and MN treatment was significantly higher than that in $\mathrm{LN}$ and $\mathrm{HN}$ treatment. In addition, no significant difference in nitrogen fertilizer treatments at 14, 21, and 35 days after anthesis was noted.

\section{Antioxidant enzyme activity and MDA content}

SOD activity in leaves of JQ2 initially increased and subsequently decreased with the advancing growth period (Table 6). No significant difference in SOD activity among different nitrogen fertilizer treatments was noted at 35 days after anthesis. In addition, the SOD activity in MN treatment was the strongest in the other stages. POD activity in leaves of JQ2 initially increased and subsequently decreased with the advancing growth period. No significant difference in POD activity among different nitrogen fertilizer treatments was noted at 7 and 28 days after anthesis, and the POD activity in MN treatment was the strongest in the other stages. CAT activity in leaves of JQ2 initially increased and subsequently decreased with the advancing growth period. The CAT activity was the strongest in MN treatment than the other nitrogen fertilizer treatments. MDA content in leaves of JQ2 increased continuously with advancing growth period. The MDA content in HN treatment was significantly higher than that in the other three nitrogen fertilizer treatments and the lowest in MN treatment.

\section{Agronomic traits and yield}

The applications of nitrogen fertilizer had little effect on the height of JQ2, i.e., no significant differences in plant height were noted (Table 7). The values of all the six agronomic traits (number of main stem nodes, number of main stem branches, grain number per plant, grain weight per plant, and 1000grain weight) in $\mathrm{MN}$ treatment were higher than those in the other three treatments. In addition, the yield was significantly higher in MN treatment than those of the others, and the lowest yield was found in the $0 \mathrm{~N}$ treatment.

All the results shown in Table 1-Table 7 were obtained from the experiment in 2019. The results from the experiment in 2020 gave a similar trend.

\section{DISCUSSION}

Grain filling stage is an important physiological stage of crop growth. The grain filling process is closely related to the yield formation [24]. In the current study, Richards' equation was used to fit the grain filling process of JQ2 under different nitrogen fertilizer treatments, and the fitting degree was higher than 0.986. These findings indicated that the continuous process of grain quality of JQ2 could be quantitatively expressed by Richards' growth curve. The curve is a cluster of curves determined by the size of $N$ values. From the results of the present experiment, the $N$ values of JQ2 under different nitrogen fertilizer treatments were 0.0018 to 0.0061 . When $0<N<1$, the growth curve is to the left. Thus, the filling material is relatively sufficient, which shows that the grain filling material grows rapidly at the early filling stage, and then gradually weakens [18]. From the results of the current experiment, the filling initiation potential of MN treatment was found to be higher than those of the other three nitrogen fertilizer treatments. This finding implied that the grain filling of JQ2 started early, preferentially obtaining photosynthetic products, and reached the maximum filling rate in a short time after flowering. These data suggested that the time for MN treatment to reach the maximum filling rate is less than those of other nitrogen fertilizer 
Table 6 Effect of different nitrogen fertilizer treatments on antioxidant enzyme activity and MDA content of JQ2.

\begin{tabular}{|c|c|c|c|c|c|c|}
\hline Enzyme/Metabolite & Treatment & $7 \mathrm{~d}$ & $14 \mathrm{~d}$ & $21 \mathrm{~d}$ & $28 \mathrm{~d}$ & $35 \mathrm{~d}$ \\
\hline $\mathrm{SOD}(\mathrm{U} / \mathrm{mg})$ & $\begin{array}{l}\text { ON } \\
\text { LN } \\
\text { MN } \\
\text { HN }\end{array}$ & $\begin{array}{l}124.707^{\mathrm{c}} \\
182.805^{\mathrm{b}} \\
219.190^{\mathrm{a}} \\
165.493^{\mathrm{b}}\end{array}$ & $\begin{array}{l}245.599^{b} \\
231.807^{c} \\
306.338^{a} \\
185.199^{d}\end{array}$ & $\begin{array}{l}262.559^{\mathrm{b}} \\
265.012^{\mathrm{b}} \\
349.765^{\mathrm{a}} \\
197.840^{\mathrm{c}}\end{array}$ & $\begin{array}{l}294.601^{b} \\
246.772^{c} \\
351.526^{a} \\
285.211^{b c}\end{array}$ & $\begin{array}{l}224.178^{\mathrm{a}} \\
239.730^{\mathrm{a}} \\
238.556^{\mathrm{a}} \\
237.382^{\mathrm{a}}\end{array}$ \\
\hline POD (nmol/min/g) & $\begin{array}{l}\text { ON } \\
\text { LN } \\
\text { MN } \\
\text { HN }\end{array}$ & $\begin{array}{l}33.157^{\mathrm{a}} \\
29.605^{\mathrm{a}} \\
30.521^{\mathrm{a}} \\
28.471^{\mathrm{a}}\end{array}$ & $\begin{array}{l}35.150^{\mathrm{b}} \\
46.563^{\mathrm{a}} \\
45.676^{\mathrm{a}} \\
35.501^{\mathrm{b}}\end{array}$ & $\begin{array}{l}67.969^{\mathrm{b}} \\
49.633^{\mathrm{c}} \\
79.482^{\mathrm{a}} \\
52.267^{\mathrm{c}}\end{array}$ & $\begin{array}{l}58.815^{\mathrm{a}} \\
54.614^{\mathrm{a}} \\
52.434^{\mathrm{a}} \\
50.046^{\mathrm{a}}\end{array}$ & $\begin{array}{l}38.819^{\mathrm{b}} \\
46.663^{\mathrm{a}} \\
46.766^{\mathrm{a}} \\
42.499^{\mathrm{ab}}\end{array}$ \\
\hline CAT $(\mathrm{nmol} / \mathrm{min} / \mathrm{g})$ & $\begin{array}{l}\text { ON } \\
\text { LN } \\
\text { MN } \\
\text { HN }\end{array}$ & $\begin{array}{l}258.333^{\mathrm{b}} \\
291.667^{\mathrm{a}} \\
308.333^{\mathrm{a}} \\
300.000^{\mathrm{a}}\end{array}$ & $\begin{array}{l}266.667^{\mathrm{c}} \\
350.667^{\mathrm{b}} \\
500.000^{\mathrm{a}} \\
350.000^{\mathrm{b}}\end{array}$ & $\begin{array}{l}338.333^{c} \\
491.667^{b} \\
791.667^{a} \\
316.667^{c}\end{array}$ & $\begin{array}{l}291.667^{\mathrm{b}} \\
258.333^{\mathrm{b}} \\
408.333^{\mathrm{a}} \\
266.667^{\mathrm{b}}\end{array}$ & $\begin{array}{l}216.667^{\mathrm{c}} \\
250.333^{\mathrm{b}} \\
383.333^{\mathrm{a}} \\
225.667^{\mathrm{bc}}\end{array}$ \\
\hline MDA ( $\mu \mathrm{mol} / \mathrm{g})$ & $\begin{array}{l}\text { ON } \\
\text { LN } \\
\text { MN } \\
\text { HN }\end{array}$ & $\begin{array}{l}0.246^{\mathrm{b}} \\
0.248^{\mathrm{b}} \\
0.163^{\mathrm{c}} \\
0.404^{\mathrm{a}}\end{array}$ & $\begin{array}{l}0.577^{\mathrm{b}} \\
0.519^{\mathrm{b}} \\
0.342^{\mathrm{c}} \\
0.666^{\mathrm{a}}\end{array}$ & $\begin{array}{l}0.707^{\mathrm{b}} \\
0.707^{\mathrm{b}} \\
0.703^{\mathrm{b}} \\
0.821^{\mathrm{a}}\end{array}$ & $\begin{array}{l}0.771^{\mathrm{b}} \\
0.771^{\mathrm{b}} \\
0.708^{\mathrm{b}} \\
0.961^{\mathrm{a}}\end{array}$ & $\begin{array}{l}1.150^{\mathrm{b}} \\
0.966^{\mathrm{c}} \\
0.735^{\mathrm{d}} \\
1.750^{\mathrm{a}}\end{array}$ \\
\hline
\end{tabular}

Table 7 Agronomic traits and yield of JQ2.

\begin{tabular}{|c|c|c|c|c|c|c|c|}
\hline Treatment & $\begin{array}{l}\text { Plant height } \\
(\mathrm{cm})\end{array}$ & $\begin{array}{l}\text { No. of main } \\
\text { stem nodes }\end{array}$ & $\begin{array}{l}\text { No. of branches } \\
\text { of main stem }\end{array}$ & $\begin{array}{l}\text { Grain no. per } \\
\text { plant (grain) }\end{array}$ & $\begin{array}{l}\text { Grain weight per } \\
\text { plant }(\mathrm{g})\end{array}$ & $\begin{array}{l}\text { 1000-grain } \\
\text { weight }(\mathrm{g})\end{array}$ & $\begin{array}{c}\text { Yield } \\
\text { (kg/ha) }\end{array}$ \\
\hline ON & $120.867^{\mathrm{a}}$ & $11.333^{b}$ & $8.000^{\mathrm{ab}}$ & $492.333^{d}$ & $12.577^{b}$ & $22.095^{\mathrm{c}}$ & $853.0^{\mathrm{d}}$ \\
\hline $\mathrm{LN}$ & $124.467^{\mathrm{a}}$ & $10.333^{b}$ & $8.667^{\mathrm{ab}}$ & $520.333^{\mathrm{b}}$ & $13.193^{\mathrm{a}}$ & $27.065^{b}$ & $1015.7^{c}$ \\
\hline MN & $126.600^{\mathrm{a}}$ & $15.333^{\mathrm{a}}$ & $9.667^{\mathrm{a}}$ & $608.000^{\mathrm{a}}$ & $13.860^{\mathrm{a}}$ & $30.361^{\mathrm{a}}$ & $1508.5^{\mathrm{a}}$ \\
\hline $\mathrm{HN}$ & $138.333^{\mathrm{a}}$ & $11.667^{b}$ & $7.333^{b}$ & $503.667^{c}$ & $13.097^{\mathrm{a}}$ & $26.536^{b}$ & $1275.0^{\mathrm{b}}$ \\
\hline
\end{tabular}

treatments.

SOD, POD, and CAT play an important role in scavenging oxygen free radicals in organisms. They are very important protective enzymes in the process of active oxygen metabolism in plants [25]. In addition, together with MDA, these enzymes are often used as a physiological and biochemical index to measure plant senescence. Xu et al [26] found that the activities of SOD and POD were negatively correlated with the senescence of buckwheat leaves. On the other hand, the MDA content was positively correlated with the senescence of buckwheat leaves. The results of $\mathrm{He}$ et al [27] showed that the insufficient nitrogen supply in soil led to an increase of MDA content and decreases of SOD, POD, and CAT enzyme activities, ROS accumulation, and leaf senescence acceleration. With the increase in nitrogen application rate, the MDA content of corn decreased, and the POD, CAT, and SOD activities increased. These changes delayed the senescence of corn to a certain extent. Based on the results of the current experiment, the SOD, POD, and CAT enzyme activities were found to be the strongest, and the MDA content was the lowest, under MN treatment. Increasing or decreasing the amount of nitrogen fertilizer will also reduce the SOD, POD, and CAT enzyme activities and increase the MDA content. These results were consistent with those of Ye et al [28]. Our data reveal that excessive or insufficient nitrogen fertilizer accelerates the leaf senescence and reduces the final yield of the JQ2.

\section{CONCLUSION}

Suitable nitrogen fertilizer treatment (MN) can improve the efficiency of light energy utilization and provide sufficient source. In addition, MN increases filling material, promotes the filling of Tartary buckwheat, and increases grain weight. Furthermore, MN could increase SOD, POD, and CAT activities in Tartary buckwheat leaves, decrease MDA content, delay leaf senescence, and increase the yield.

Acknowledgements: We acknowledge the support of the Science and Technology Support Plan of Guizhou province, China (QianKeHe ZhiCheng [2021] yiban 271 and [2019]2297), and the Major Research Projects of Innovation Groups of Guizhou province, China (QianJiaoHe KY Zi [2017]033 and [2018]015), and the science and technology projects of Guiyang, China (Zhuke Hetong [2019]11-6).

\section{REFERENCES}

1. Wijngaard HH, Arendt EK (2006) Buckwheat. Cereal Chem 83, 391-401.

2. Ge RH, Wang H (2020) Nutrient components and bioactive compounds in Tartary buckwheat bran and flour as affected by thermal processing. Int $J$ Food Prop 23, 127-137. 
3. Giménez-Bastida JA, Zieliński H (2015) Buckwheat as a functional food and its effects on health. $J$ Agric Food Chem 63, 7896-7913.

4. Song YX, Guo X, Yang LY, Chen QF, Huang KF (2014) Effects of different NPK treatments on the yield and plumpness of Tartary buckwheat. Acta Agri Zhejiangensis 26, 1568-1572. [in Chinese]

5. Venkateswarlu B, Visperas RM (1987) Source-sink relationships in crop plants. Int Rice Res Inst Res Pap Ser 125, 1-19.

6. Panda BB, Sekhar S, Dash SK, Behera L, Shaw BP (2018) Biochemical and molecular characterization of exogenous cytokinin application on grain filling in rice. BMC Plant Biol 18, ID 89.

7. Nooden LD, Guiamet JJ, John I (1997) Senescence mechanisms. Physiol Plant 101, 746-753.

8. Duan LS, He ZP (1996) Effects of DPC on leaf development and active oxygen metabolism in cotton. Cotton Sci 6, 312-315. [in Chinese]

9. Zhang JX, Kirkham MB (1994) Drought-stressinduced changes inactivities of superoxide dismut ase, cat alase, and peroxidase in wheat specie. Plant Cell Physiol 35, 785-791.

10. Tang G (2010) Study on the relationship between active oxygen antioxidant enzymes and antioxidants. J Anhui Agric Sci 38, 18619-18621. [in Chinese]

11. Wei DZ, Ning SJ (2002) Effects of zeatin and abscisic acid on photosynthetic performance of wheat leaves. Acta Agric Boreali Sin S1, 23-28. [in Chinese]

12. Zhang JH, Sui XZ, Li B, Su BL, Li JM, Zhou DX (1998) An improved water-use efficiency for winter wheat grown under reduced irrigation. Field Crop Res 59, 91-98.

13. Thomas H, Smart CM (1993) Crops that stays green. Ann Appl Biol 123, 193-219.

14. Xu Y, Wang LL, Chen W, Li HB, Deng XP (2013) Effects of different nitrogen levels on grain-filling characteristics and yield of two dry land wheat cultivars for superior and inferior grain. $J$ Triticeae Crops 33, 489-494. [in Chinese]

15. Jiang LN, Dai XM, Shang YL, Hong ZX (2000) The relationship between nitrogen nutrition and leaf senescence in the later stage of wheat. $J$ Triticeae Crops 20, 39-41. [in Chinese]

16. Ma DY, Guo TC, Wang CY, Zhu YJ, Wang YH, Yue YJ, Song X, Cha FN (2006) Effects of nitrogen fertilizer applied at different development stages on the activities of photosynthetic enzymes in winter wheat flag leaves. Plant Physiol Commun 42, 1091-1095. [in Chinese]
17. Liang CG, Song YX, Guo X, Kong DZ, Wang Y, Zhao Q, Huang KF (2016) Characteristics of the grainfilling process and starch accumulation of high-yield common buckwheat 'cv. Fengtian 1' and Tartary buckwheat 'cv. Jingqiao 2'. Cereal Res Commun 44, 393-403.

18. Wang Y, Song YX, Zhang Y, Kong DZ, Zhao Q, Lin JQ, Huang KF (2017) Characteristics of starch synthesis and grain filling of common buckwheat. $J$ Cereal Sci 73, 116-121.

19. Yang ZY, Sun YJ, Xu H, Qin J, Jia XW, Ma J (2013) Influence of cultivation methods and no-tillage on root senescence at filling stage and grain-filling properties of Eryou 498. Sci Agric Sin 46, 1347-1358. [in Chinese]

20. Yang J, Zhang J, Wang Z, Zhu Q, Liu L (2003) Activities of enzymes involved in source-to-starch metabolism in rice grains subjected to water stress during filling. Field Crops Res 81, 69-81.

21. Nakamura Y, Yuki K (1992) Changes in enzyme activities associated with carbohydrate metabolism during the development of rice endosperm. Plant Sci 82, ID 15.

22. Zhang ZX (1990) Measure of Crop's Physiological Research, Agricultural Press, Beijing.

23. Zhang ZW, Lin RF (2007) Description Specification and Data Standard of Buckwheat Germplasm Resources, China Agriculture Press, Beijing.

24. Zhang Y, Wu XY, Huang XY, He PY, Chen QF, Huang KF (2020) Difference of grain filling characteristics and starch synthesis between the superior and inferior spikelet of Tartary buckwheat. Int J Agric Biol 23, 681-686.

25. Foyer CH, Descourviers P, Kunert KJ (1994) Protection againstoxygen radicals: an important defencemechanism studiedin transgenic plants. Plant Cell and Environ 17, 507-523.

26. Xu YL, Tang HM, Li YF, Xiao XP, Li WY, Sun G, Cheng KK (2017) Dynamic changes of soil microbial and enzyme activities in double-season paddy fields during long-term fertilization of barley. Chin Agric Sci Bull 33, 12-20. [in Chinese]

27. He P, Jin JY, Lin B (1998) Effect of $N$ application rates on leaf senescence and its mechanism in spring maize. Sci Agric Sin 31, 66-71. [in Chinese]

28. Ye J, Gao JL, Yu XF, Wang ZG, Sun JY, Li LJ (2011) Effects of nitrogen amounts on senescence process in leaves and yield of super-high yield spring maize during flowering and heading period. J Inn Mong Agric Univ Nat Sci Ed 32, 178-183. [in Chinese] 